\title{
PENGARUH ETIKA, PERILAKU, DAN KEPRIBADIAN TERHADAP INTEGRITAS GURU
}

\section{THE EFFECT OF ETHIC, BEHAVIOUR, AND PERSONALITY ON TEACHER'S INTEGRITY}

\author{
Sri Sarjana \\ SMKN 1 Cikarang Barat \\ Jl. Teuku Umar No 1, Cikarang Barat, Bekasi \\ e-mail: srisarjana@gmail.com \\ Nur Khayati \\ SMAN 1 Cikarang Utara \\ Jl. Ki Hajar Dewantara No. 91 Cikarang Utara, Bekasi \\ e-mail: nurkayati.pch@gmail.com
}

Naskah diterima tanggal: 4-12-2016, Direvisi akhir tanggal: 15-12-2016, disetujui tanggal: 30-12-2016

\begin{abstract}
Integrity is one of requirements for teachers as a professional educator. Teachers with integrity is a role model for students. Strengthening teachers' integrity is part of government policy to improving teacher quality in the future. The purpose of this study was to determine the effect of teachers' ethics on teachers' personality, the effect of teachers' behavior on teachers' personality, and the effect of teacher's personality on teachers' integrity. This quantitative research developed explanatory survey method and the sample was 154 senior secondary school teachers in Bekasi district. Test of statistical data analysis using Structural Equation Modeling (SEM) with 8.8 Lisrel program and using SPSS 22. The results of this study shows that ethic and behaviour of teachers have a positive influence on their personality and it affects their integrity. Ethics and behaviour of teachers have an important role in improving the integrity through the development of the personality of the teacher. Efforts of teachers in improving their integrity is an essential need and it can be implemented through improving their ethics, developing their behaviour, and promoting their better personality.
\end{abstract}

Keywords: teacher's integrity, teacher's ethic, personality effect

\begin{abstract}
Abstrak: Pendidik yang berintegritas menjadi persyaratan bagi guru sebagai tenaga pendidik yang profesional. Guru yang berintegritas menjadi teladan dan contoh yang baik bagi siswa. Perlunya penguatan integritas guru menjadi bagian penting dari kebijakan pemerintah untuk pengembangan kualitas guru di masa depan. Penelitian ini bertujuan mengkaji pengaruh etika guru terhadap kepribadian guru, pengaruh perilaku guru terhadap kepribadian guru, dan pengaruh kepribadian guru terhadap integritas guru. Data didapatkan dari 154 guru SMA negeri di Kabupaten Bekasi. Jenis penelitian adalah penelitian kuantitatif yang mengembangkan metode explanatory survey. Uji analisis data statistik menggunakan Structural Equation Modeling (SEM) dengan program Lisrel 8.8 serta menggunakan SPSS 22. Hasil penelitian ini menujukkan bahwa etika dan perilaku guru memiliki pengaruh positif terhadap kepribadian dan berdampak terhadap integritas guru. Etika dan perilaku guru memiliki peran penting dalam meningkatkan integritas melalui pengembangan kepribadian guru. Kontribusi guru dalam meningkatkan nilai integritas sangat diperlukan melalui upaya memperbaiki etika, mengembangkan perilaku, dan mengedepankan kepribadian yang lebih baik.
\end{abstract}

Kata kunci: integritas guru, etika guru, pengaruh kepribadian 


\section{PENDAHULUAN}

Pendidikan merupakan proses pengubahan sikap dan tata laku seseorang atau kelompok orang dalam usaha mendewasakan manusia melalui upaya pengajaran dan latihan (Susanna, 2014). Pendidik adalah penentu generasi muda untuk masa depan karena di tangan pendidiklah generasi muda akan menjadi generasi yang tangguh dan siap melanjutkan estafet kepemimpinan yang lebih damai dan sejahtera (Ninoersy, 2015). Pendidik mengabdikan diri dan berbakti untuk mencerdaskan kehidupan bangsa dan meningkatkan kualitas manusia yang beriman, bertakwa, dan berakhlak mulia serta menguasai ilmu pengetahuan, teknologi, dan seni dalam mewujudkan masyarakat yang maju, adil, makmur, dan beradab. Pendidik selalu tampil secara profesional dengan tugas utama mendidik, mengajar, membimbing, dan mengarahkan (Gade, 2015). Pendidik merupakan tenaga pengajar profesional yang merupakan unsur yang sangat penting dari proses pendidikan. Pendidik mempunyai tanggung jawab yang amat besar dalam mengantarkan peserta didik ke arah tujuan pendidikan yang dicita-citakan dan relevan dengan perkembangan zaman. Pendidik profesional juga merupakan kumpulan kepribadian yang bersifat dinamis ke arah suatu perubahan secara terus-menerus, bahkan sebagai sasaran yang sangat urgen untuk membangun kebudayaan dan peradaban umat manusia. Pendidik yang profesional bertanggung jawab untuk memenuhi kebutuhan peserta didik dalam berbagai bidang baik spiritual, intelektual, moral, etika, maupun kebutuhan fisik peserta didik serta memahami etika profesi dalam menjalankan tugasnya secara profesional. Oleh karena itu, pendidik yang profesional harus memiliki integritas mutu dan sifat yang menunjukkan kesatuan yang utuh sehingga memiliki potensi dan kemampuan yang memancarkan kewibaan dan kejujuran (Ninoersy, 2015). Pendidikan yang memenuhi etika adalah pendidikan yang memiliki akuntabilitas yang tinggi dalam penyelenggaraannya (Karwati, 2011).
Seringkali sifat kepribadian guru dalam proses pembelajaran kurang membangun motivasi belajar peserta didik (Rosmiati, Juraid, \& Hasan, 2016).

Profesionalisme pendidik haruslah memenuhi kebutuhan peserta didik dalam berbagai bidang baik spiritual, intelektual, moral, etika, maupun kebutuhan fisik serta memahami etika profesi dalam menjalankan tugasnya. Pendidik yang profesional harus memiliki integritas mutu dan sifat yang menunjukkan kesatuan utuh sehingga memiliki potensi dan kemampuan yang memancarkan kewibawaan dan kejujuran (Ninoersy, 2015). Integritas sering dipahami dalam konteks perilaku, dan perilaku integritas pada umumnya dipahami dalam kaitannya dengan etika dan moral. Keadaan berperilaku dengan integritas diharapkan muncul bukan hanya karena tuntutan pekerjaan yang mengharuskan seseorang untuk berintegritas tetapi karena individu tersebut memahami dengan baik bahwa memiliki integritas adalah bagian dari proses untuk membangun sesuatu yang lebih baik di dalam keluarga, organisasi atau negara (SriRedjeki \& Heridiansyah, 2013).

Kebijakan Menteri Pendidikan dan Kebudayaan Anies Baswedan pada tahun 2016 terkait dengan pengumuman indeks integritas ujian nasional yang mengukur tingkat kejujuran siswa dalam mengerjakan ujian nasional serta mengukur tingkat kejujuran sekolah dalam mengadakan ujian nasional sangatlah diapresiasi. Pengembangan integritas di sekolah baik kepala sekolah, guru maupun siswa merupakan hal yang sangat penting dalam rangka menghasilkan individu yang berintegritas tinggi sehingga penguatan integritas pendidikan menjadi tugas bersama bagi seluruh civitas sekolah. Rata-rata indeks integritas ujian nasional SMA tahun 2016 secara nasional sebesar 64,05. Sedangkan rata-rata indeks integritas ujian nasional SMA tahun 2015 secara nasional sebesar 61,98. Peningkatan sebesar 2,06 poin menunjukkan adanya perubahan perilaku siswa dan peningkatan kejujuran sekolah ke arah yang lebih baik meskipun secara 
keseluruhan nilai indeks tersebut masih belum memuaskan. Dari 39 SMA Negeri di Kabupaten Bekasi, hanya terdapat 7 sekolah yang terdiri dari 1 sekolah jurusan IPA dan 6 sekolah jurusan IPS dengan indeks integritas diatas 80 . Hal ini berarti bahwa hanya sekitar 20,5\% SMA Negeri di Kabupaten Bekasi memiliki indeks integritas yang sesuai dengan harapan stakeholder sedangkan indeks sebesar $79,5 \%$ belum sesuai dengan harapan pemangku kepentingan.

Rumusan masalah dalam penelitian ini yaitu a) bagaimana pengaruh etika guru terhadap kepribadian; b) bagaimana pengaruh perilaku guru terhadap kepribadian; dan c) bagaimana pengaruh kepribadian guru terhadap integritas. Tujuan penelitian ini yaitu untuk mengkaji: a) pengaruh etika guru terhadap kepribadian; b) pengaruh perilaku guru terhadap kepribadian; dan c) pengaruh kepribadian guru terhadap integritas khususnya guru-guru SMA Negeri di Kabupaten Bekasi.

Integritas adalah sebuah konstruk psikologis yang dinamis berdasarkan berfungsinya kepribadian dengan baik yang dikelola oleh fungsi kognitif, afektif, dan didukung oleh kemampuan tertentu untuk mewujudkannya ke dalam perilaku integritas (Sri-Redjeki \& Heriansyah, 2013). Integritas merujuk pada kejujuran dan kebenaran (Robbins \& Judge, 2013). Integritas adalah kekuatan personal yang membentuk seseorang dapat dipercaya oleh pihak lain sehingga individu tersebut akan dapat mencapai tujuan yang telah ditetapkan secara efektif, dengan indikator antara lain jujur, bertanggung jawab, dapat dipercaya, loyal atau patuh pada aturan, dan memberi manfaat untuk orang lain (Sunengsih, 2015). Integritas adalah fondasi bagi kepemimpinan yang membuatnya bisa melaksanakan dan menghasilkan kinerja kepemimpinan etis (Gea, 2014). Integritas adalah suatu hal yang baik dan penting di dalam kehidupan organisasi (Audi \& Murphy, 2006). Integritas mampu menjadikan seorang individu memiliki karakter dan nilai-nilai dasar sebagai benteng penyakit-penyakit sosial, seperti korupsi, manipulasi, kolusi dan nepotisme (SriRedjeki \& Heridiansyah, 2013).

Keadaan berperilaku dengan integritas diharapkan muncul bukan hanya karena tuntutan pekerjaan yang mengharuskan seseorang untuk berintegritas tetapi karena individu tersebut memahami dengan baik bahwa memiliki integritas adalah bagian dari proses untuk membangun sesuatu yang lebih baik di dalam keluarga, organisasi, atau negara (SriRedjeki \& Heridiansyah, 2013). Orang yang memiliki integritas adalah orang yang dianggap baik, panutan, yang dapat dipercaya, orang yang setia, jujur, jauh dari kepalsuan dan kepurapuraan, menjadi teladan dalam banyak hal (Gea, 2014). Perilaku yang berintegritas mencakup jujur, konsisten antara ucapan dan tindakan, mematuhi peraturan dan etika berorganisasi, memegang teguh komitmen dan prinsip-prinsip yang diyakini benar, bertanggung jawab atas tindakan, keputusan, dan resiko yang menyertainya, kualitas individu untuk mendapatkan rasa hormat dari orang lain, kepatuhan yang konsisten pada prinsip-prinsip moral yang berlaku di masyarakat, kearifan dalam membedakan benar dan salah serta mendorong orang lain untuk melakukan hal yang sama (SriRedjeki \& Heridiansyah, 2013).

Orang yang memiliki integritas adalah orang yang dianggap baik, menjadi panutan, dapat dipercaya, setia, jujur, jauh dari kepalsuan dan kepura-puraan, menjadi teladan dalam banyak hal (Gea, 2014). Integritas secara aktif terinternalisasi sebagai rasa keutuhan dan keseimbangan dalam individu yang menyadari konteks diri dan memiliki keyakinan moral, serta konsisten untuk mewujudkannya ke dalam perilaku, tanpa harus merasa malu dan berani untuk menyebarkan keyakinannya (Sri-Redjeki \& Heridiansyah, 2013). Dengan integritas diri yang dimiliki maka kompetensi bisa lebih terarah untuk menghasilkan kinerja baik dan berkualitas (Gea, 2014).

Kepribadian adalah keseluruhan dari individu yang terdiri dari unsur psikis dan fisik (Djamarah, 
2010). Kepribadian dalam psikologi diartikan sebagai suatu organisasi yang dinamis dari sistem psikofisik individu yang menentukan pemikiran, sikap dan tingkah laku individu secara khas (Rosyidi, 2012). Kepribadian adalah sesuatu sikap atau tingkah laku yang dimiliki oleh seseorang dalam melaksanakan suatu kegiatan yang menjadi tanggung jawabnya untuk menentukan suatu tujuan (Susanna, 2014). Kepribadian merupakan akhlak, berakhlak mulia, arif dan berwibawa serta menjadi teladan peserta didik berkepribadian yang mantap (Susanna, 2014). Kepribadian setiap individu akan membentuk perilaku individu. Kepribadian merupakan gabungan dari ciri-ciri fisik dan mental yang stabil dari setiap individu yang menandakan identitas individu tersebut sehingga berbeda antara setiap individu yang satu dengan individu lainnya (Robbins \& Judge, 2013).

Dimensi kepribadian berupa harga diri, kemandirian, dan kepribadian tahan banting dan harga diri (Hadjam, 2013). Kepribadian merupakan trait bawaan sejak lahir, sedangkan karakter merupakan perilaku hasil pembelajaran (Nofijantie, 2014). Sifat kepribadian adalah faktor yang sangat berpengaruh terhadap keberhasilan guru (Rosmiati, Juraid, \& Hasan, 2016). Kepribadian merupakan faktor yang sangat penting dalam kesuksesan seorang guru sebagai agen dalam pembelajaran. Kepribadian seorang guru akan menentukan apakah ia menjadi pendidik dan pembina yang baik bagi anak didiknya (Susanna, 2014). Setiap guru mempunyai kepribadian masing-masing sesuai ciri-ciri pribadi yang mereka miliki. Ciri-ciri inilah yang membedakan seorang guru dengan guru lainnya. Kepribadian sebenarnya adalah masalah yang abstrak, hanya dapat dilihat lewat penampilan, tindakan, ucapan, cara berpakaian, dan dalam menghadapi setiap persoalan (Djamarah, 2010). Syarat kepribadian guru menurut Peraturan Menteri Pendidikan Nasional Republik Indonesia Nomor 16 Tahun 2007 tentang standar kualifikasi akademik dan kompetensi guru diantaranya mencakup: a) bertindak sesuai dengan norma agama, hukum, sosial, dan kebudayaan nasional Indonesia, b) menampilkan diri sebagai pribadi yang jujur, berakhlak mulia dan teladan bagi peserta didik dan masyarakat, c) menampilkan diri sebagai pribadi yang mantap, stabil, dewasa, arif, dan berwibawa, d) menunjukkan etos kerja, tanggung jawab yang tinggi, rasa bangga menjadi guru, dan rasa percaya diri, e) menjunjung tinggi kode etik profesi guru.

Kepribadian guru memiliki peran dan fungsi yang sangat penting dalam membentuk kepribadian anak guna menyiapkan dan mengembangkan sumber daya manusia serta menyejahterakan masyarakat, kemajuan negara, dan bangsa pada umumnya (Susanna, 2014). Guru harus mampu menciptakan situasi yang dapat menunjang perkembangan belajar peserta didik termasuk dalam menumbuhkan motivasi belajar peserta didik. Semua ini tidak terlepas dari bagaimana guru menampilkan kemampuan sifat kepribadiannya dalam proses pembelajaran (Rosmiati, Juraid, \& Hasan, 2016). Sifat kepribadian guru mempunyai pengaruh langsung dan kumulatif terhadap perilaku peserta didik. Perilaku yang berpengaruh itu antara lain kebiasaan belajar, disiplin, hasrat belajar, dan motivasi belajar. Yang dimaksud dengan sifat kepribadian meliputi pengetahuan, keterampilan, dan sikap. Sifat kepribadian yang ditampilkan guru dalam proses pembelajaran akan selalu dilihat, diamati, dan dinilai oleh peserta didik sehingga timbul dalam diri peserta didik persepsi tertentu tentang sifat kepribadian guru (Hamalik, 2000).

Definisi etika menurut Ferrel (2013) adalah studi tentang sifat moral dan pilihan moral yang spesifik, filsafat moral, dan aturan-aturan atau standar yang mengatur perilaku para anggota profesi. Etika merupakan cabang ilmu filsafat berkaitan dengan konsep nilai-nilai yang baik dan menjadi panutan dalam hubungan kemanusiaan antar manusia seperti kebenaran, kebebasan, kejujuran, keadilan, cinta, kasih sayang yang terkait norma moralitas (Lubis, 2011). Etika adalah studi tentang standar moral dan pengaruhnya terhadap perilaku (Dutelle, 
2011). Etika kerja adalah seperangkat perilaku yang dimiliki oleh individu atau kelompok yang diimplementasikan dalam bekerja atau beraktivitas untuk mencapai tujuan yang telah ditetapkan dengan dilandasi nilai-nilai dan norma-norma yang dianut dengan indikator tepat waktu, jujur, memiliki motivasi untuk berkembang, bekerja keras, bertanggung jawab, kreatif dan menghormati dan menghargai (Sarjana, 2014). Etika atau filsafat moral yaitu mengacu pada kehidupan yang baik, tentang apa yang baik dan buruk, tentang apakah ada tujuan yang benar dan salah, dan bagaimana mengetahui hal itu ada (Mackinnon, 2013).

Hakikat kehidupan yang baik dalam pengelolaan pendidikan khususnya pada satuan pendidikan, pada dasarnya berkaitan dengan norma dan tata nilai kehidupan yang telah menjadi pola anutan masyarakat yaitu etika dan moralitas (Karwati, 2011). Dalam kode etik guru disebutkan bahwa guru memelihara hubungan seprofesi, semangat kekeluargaan, dan kesetiakawanan sosial. Hal ini berarti bahwa guru hendaknya menciptakan dan memelihara hubungan sesama guru dalam lingkungan kerja. Selain itu, guru hendaknya menciptakan dan memelihara semangat kekeluargaan dan kesetiakawanan sosial baik di dalam maupun di luar lingkungan kerja (Sarjana, 2014).

Perilaku organisasi adalah ilmu perilaku manusia dalam pengaturan organisasi, yang menghubungkan antara perilaku manusia dan organisasi (Griffin \& Moorhead, 2014). Perilaku organisasi adalah bidang studi yang mempelajari dampak individu, kelompok, dan stuktur yang dimiliki dalam perilakunya dalam organisasi yang bertujuan untuk mengaplikasikan pengetahuan terhadap peningkatan efektivitas organisasi (Robbins \& Judge, 2013). Perilaku organisasi mempelajari apa saja yang yang dikerjakan orang dalam organisasi dan bagaimana perilaku dan tindakan itu bisa mempengaruhi tampilan organisasi (Muchlas, 2008).

Standar perilaku pendidik dalam pembelajaran meliputi kejujuran, keterbukaan, dan demokrasi (Silahuddin, 2016). Dalam melak- sanakan tugas profesi pendidik, perlu ditetapkan kode etik pendidik sebagai pedoman bersikap dan berperilaku dalam bentuk nilai-nilai moral dan etika dalam jabatan sebagai pendidik putera-puteri bangsa. Pedoman sikap dan perilaku yang dimaksud adalah nilai-nilai moral yang membedakan perilaku pendidik yang baik dan perilaku pendidik yang buruk, yang boleh dan yang tidak boleh dilaksanakan selama melaksanakan tugas-tugas profesionalnya untuk mendidik, mengajar, membimbing, mengarahkan, melatih, menilai, dan mengevaluasi peserta didik, serta sikap pergaulan sehari-hari di dalam dan luar sekolah (Gade, 2015). Tugas guru membantu mengkondisikan siswa terhadap sikap, perilaku atau kepribadian yang benar, agar mampu menjadi agen modernisasi bagi dirinya sendiri, lingkungan, masyarakat dan siapa saja yang dijumpai tanpa harus membedakan suku, agama, ras dan golongan (Nofijantie, 2014). Perilaku pendidik dipandang sebagai sumber pengaruh yang dapat memberi efek kepada siswa (Sahriansyah, Yulizar, \& Khaliq, 2015). Kecerdasan emosi memberi arah perilaku guru dalam berinteraksi dengan orang lain dan mendorong diri guru lebih mampu mengembangkan empati serta menghindarkan seseorang berperilaku negatif dan menyimpang (Muryadi \& Matulessy, 2012).

Mengacu pada landasan teori dan model penelitian yang dikembangkan maka hipotesis penelitian dapat dijabarkan sebagai berikut: $\mathrm{H}_{1}=$ Etika berpengaruh positif terhadap kepribadian

$\mathrm{H}_{2}=$ Perilaku berpengaruh positif terhadap kepribadian

$\mathrm{H}_{3}=$ Kepribadian berpengaruh positif terhadap integritas

Pemahaman visi pekerjaan sesuai etika profesi perlu dipahami agar tuntutan yang diberikan kepada guru bukan dianggap sebagai beban melainkan visi yang akan dicapai guru melalui proses belajar mengajar (Munir, 2009). Etika guru mengatur hubungan kemanusiaan antara guru dengan sekolah, guru dengan sesama guru, guru dengan peserta didik, guru 


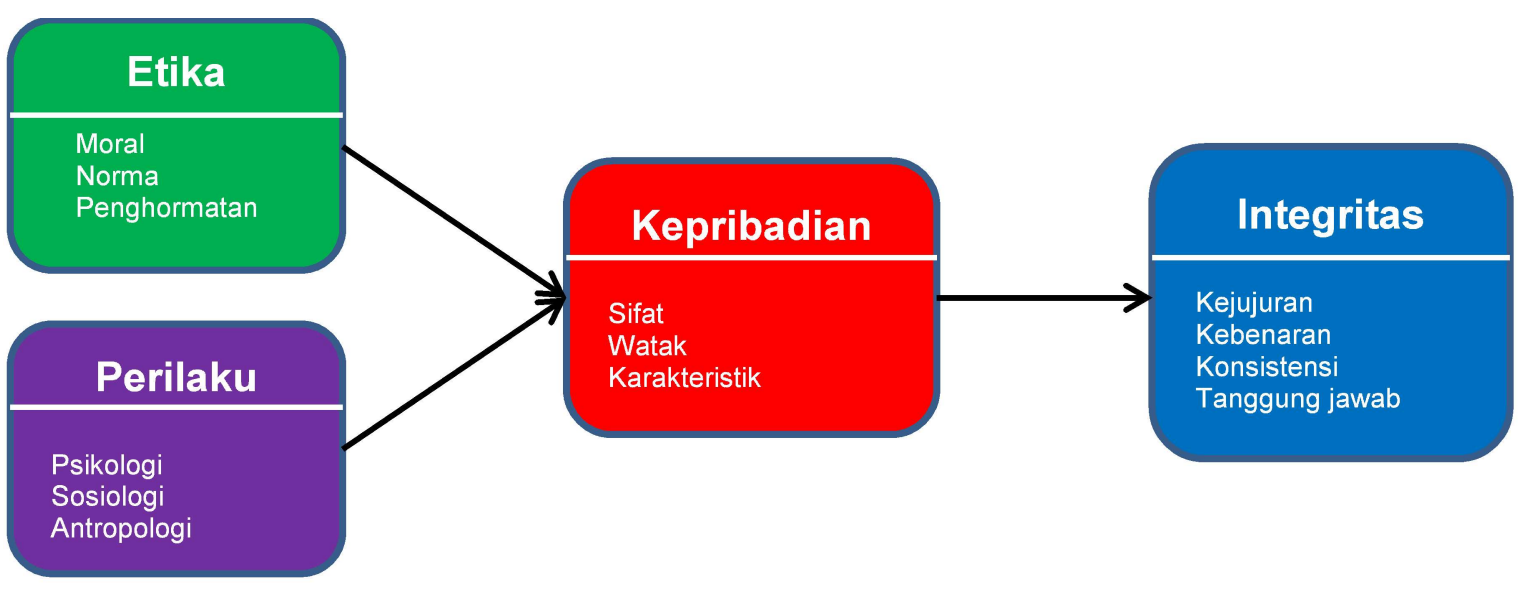

Gambar 1. Model Penguatan Integritas Pendidik

dengan lingkungannya (Sarjana, 2014). Kurikulum yang sudah divalidasi bagi pimpinan merupakan suatu kebutuhan dengan tanggung jawab seperti komunikasi, manajemen keuangan, keterampilan, menetapkan sasaran yang tepat dengan visi yang jelas, penanganan emosi dengan profesional dan beretika (Chari, Gupta \& Gade, 2016). Tanggung jawab secara etika memberikan solusi yang terbaik, tepat dan berkelanjutan bagi mitra masyarakat (Bielefeldt, Swan, Canney \& Knight, 2016). Pentingnya memenuhi prinsip-prinsip etika dan moral (Groisman \& Godard, 2016). Adanya kebutuhan dalam pengembangan kapasitas dalam menerapkan prinsip pemikiran guna mengatasi masalah etika (Verrinder, Ostini \& Phillips, 2016).

Perilaku guru merupakan penampilan dari kepribadiannya (Navisah, 2009). Kepribadian dan karakter guru yang matang dan kokoh dapat menjadi teladan dan menjadi sumber inspirasi bagi siswanya (Nursyamsi, 2014). Identitas dan perilaku kerja secara ideal perlu mengadopsi etika sebagai gaya hidup untuk membentuk hal positif (Linstrom, 2016). Guru yang baik mendorong siswa untuk berperilaku baik dan memberikan layanan terbaik untuk masyarakat, sementara guru pemarah akan mengarahkan siswa melakukan penyimpangan dalam perilakunya (Rahrovan, 2016). Proses perubahan mampu mengindikasikan perubahan perilaku (Mermer, Daghan, \& Bilge, 2016). Kedekatan tempat bekerja berkorelasi dengan perubahan perilaku (You, Wang, \& Tan, 2016). Perilaku tidak hanya mencakup perilaku yang dilakukan untuk memenuhi kebutuhan akan peran dan tugas (Mesbahi, 2016). Keyakinan guru terkait hakikat pengetahuan memiliki kepercayaan dalam bentuk sikap, motivasi dan perilaku (Rice \& Foster, 2016).

Kepribadian guru merupakan faktor penentu keberhasilan belajar siswa (Nursyamsi, 2014). Kepribadian guru merupakan titik tumpu sebagai penyeimbang antara pengetahuan mengenai pendidikan dan keterampilan melaksanakan profesi sebagai pendidik terutama dalam bidang pembelajaran. Jika titik tumpu ini lemah, yaitu dalam keadaan kepribadian guru yang tidak banyak membantu, maka pengetahuan dan keterampilan guru tidak akan efektif digunakan, bahkan dapat merusak keseluruhan proses dan hasil pendidikan (Surya, 2013). Kepribadian yang sehat menyangkut masalah tanggung jawab, kesadaran moral dan etika, kemasyarakatan maupun diri sendiri (Nursyamsi, 2014). Kepribadian sebagai kombinasi karakteristik mental yang digunakan untuk mengklasifikasikan individu dalam perilaku dan sikap (Sadr \& Jenaabadi, 2015). Ciri-ciri kepribadian terkait dengan aspek individu dan berfungsi di tempat kerja (Mroz \& Kaleta, 2016).

Kinerja guru tercermin dari komitmen guru terhadap tupoksi, motivasi yang tinggi, keterampilan profesional, berorientasi budaya mutu, kerjasama tim dan integritas tinggi yang 
dapat berkontribusi terhadap terwujudnya mutu pendidikan di sekolah (Usman, 2010). Integritas guru menjadi faktor utama yang mesti ditingkatkan dan dikedepankan agar para murid dapat meneladani sikap dan teladan hidup guru (Tanhidy, 2015). Untuk melandasi tujuan pendidikan nasional, diwujudkan dalam integritas pribadi dan perilaku sehari-hari (Dianti, 2014). Pembangunan berkelanjutan secara progresif bagi kepribadian menjadi subyek kehidupan dan subyek sosial yang bertanggung jawab sekaligus sebagai kelompok yang berintegritas (Kabus, 2017).

\section{METODE}

Tujuan utama penelitian ini untuk mengetahui pengaruh etika dan perilaku terhadap kepribadian dan dampaknya terhadap integritas guru. Penelitian ini mengembangkan operasionalisasi variabel untuk memperoleh data dan informasi dari variabel yang diteliti yaitu etika, perilaku, kepribadian dan integritas. Pengamatan memanfaatkan cakupan waktu yang bersifat cross-sectional sehingga informasi atau data yang diperoleh merupakan hasil penelitian yang dilakukan dalam suatu waktu tertentu. Jenis penelitian ini adalah penelitian kuantitatif yang mengembangkan metode explanatory survey guna melakukan prosedur pengujian hipotesis dalam menjawab rumusan masalah dan tujuan penelitian. Pengujian instrumen dilakukan melalui uji validitas untuk mengukur ketepatan dan kecermatan alat ukur dan uji reliabilitas untuk mengetahui konsistensi indikator. Penelitian ini mengembangkan rancangan penelitian survei melalui proses seleksi sampel yang didapatkan dari populasi. Teknik analisis data penelitian diuji menggunakan program SPSS 22 dan menggunakan Structural Equation Modeling (program Lisrel 8.8) yang berbasis varian atau komponen sebagai alat (tools) dalam analisis variabel serta penerapan analisis model persamaan struktural dari hubungan kausal antarvariabel yang diteliti. SEM digunakan dalam analisis data penelitian dikarenakan mampu menguji data yang kompleks secara serempak.
Populasi penelitian adalah guru-guru SMA Negeri di Kabupaten Bekasi. Data didapatkan dari 154 guru SMA negeri di Kabupaten Bekasi sebagai sampel penelitian. Metode pengambilan sampel adalah simple random sampling. Simple random sampling digunakan sebagai teknik pengumpulan data yang menggunakan sampel penelitian acak dan dikumpulkan dari keseluruhan populasi penelitian. Data kuesioner dikumpulkan dari guru SMA yang didistribusikan melalui email maupun yang dilakukan melalui proses interview secara langsung. Jumlah kuesioner yang menjadi target sampel selanjutnya dikelompokkan sehingga memiliki spesifikasi data yaitu terdapat 175 kuesioner yang dibagikan dan 21 kuesioner dianggap tidak lengkap sehingga jumlah kuesioner yang memenuhi syarat sebesar 154 . Oleh karena itu, jumlah responden dalam pengambilan sampel penelitian ini sebesar 88 persen. Data kuesioner yang didapatkan dalam pengambilan sampel penelitian ini dikumpulkan dalam rentang waktu 1 Agustus sampai dengan 30 September 2016. Operasional variabel penelitian menunjukkan dimensi dan indikator yang diimplementasikan guna mengukur variabel penelitian. Pengukuran variabel penelitian menggunakan skala Likert 5 poin untuk mendapatkan gambaran yang jelas tentang karakteristik dari masing-masing responden.

\section{HASIL DAN PEMBAHASAN}

\section{Demografi Responden}

Karakteristik demografi responden dalam penelitian ini dianalisis berdasarkan tiga kategori yaitu usia responden, masa mengajar, dan program studi. Demografi responden menjelaskan tentang kategori, frekuensi dan prosentase untuk kelengkapan data penelitian.

Profil demografi responden yang dapat dilihat pada Tabel 1 terdiri atas guru-guru SMA Negeri di Kabupaten Bekasi yang diambil sebagai sampel penelitian. Profil responden sebesar 43,5\% merupakan jumlah responden terbanyak dengan usia berkisar antara 35-50 tahun. Hal ini menunjukkan bahwa usia guru untuk bekerja lebih produktif dan profesional dalam 
Tabel 1. Demografi Guru SMA

\begin{tabular}{llrr}
\hline Profil Demografi & Kategori & Jumlah Responden & Prosentase (\%) \\
\hline Usia Responden & Kurang 25 th & 6 & 3,9 \\
& $25-35$ th & 53 & 34,4 \\
& $35-50$ th & 67 & 43,5 \\
& Lebih 50 th & 28 & 18,2 \\
\hline Masa Mengajar & Kurang 3 th & 18 & 11,7 \\
& $3-10$ th & 77 & 50,0 \\
& Lebih 10 th & 59 & 38,3 \\
\hline Program Studi & IPA & 98 & 63,6 \\
& IPS & 56 & 36,4 \\
\hline
\end{tabular}

melaksanakan proses belajar mengajar di sekolah berkisar antara 35-50 tahun. Sedangkan 50\% responden merupakan guru SMA dengan masa mengajar terbanyak yaitu antara 3-10 tahun. Pengalaman mengajar yang diindikasikan dengan masa mengajar guru sangat dibutuhkan untuk meningkatkan kualitas dan produktivitas guru dalam mengembangkan model pembelajaran yang terkini dan sesuai dengan perkembangan teknologi dan informasi. Menurut responden masa mengajar antara 3-10 tahun memiliki keaktivan dan kontribusi yang lebih baik dalam pengembangan sekolah. Data responden menunjukkan bahwa program studi pembelajaran SMA yang diampu sebesar $63,6 \%$ sebagai responden terbesar yaitu pada kategori guru yang mengajar pada mata pelajaran IPA. Hal ini berarti bahwa program studi IPA lebih diminati dan dipilih oleh siswa SMA dibandingkan dengan program studi IPS. Banyaknya siswa yang memiliki minat dan memilih program studi IPA secara langsung berdampak pada penambahan jumlah guru program studi IPA. Selain itu, siswa memiliki persepsi bahwa dengan memilih program studi IPA akan mempunyai peluang yang lebih besar dalam memilih program studi pada perguruan tinggi yang dituju setelah lulus SMA.

\section{Uji Reliabilitas}

Hasil yang diperoleh dari pengambilan sampel melalui distribusi kuesioner dilakukan dengan menggunakan uji analisis statistik. Uji analisis statistik dilakukan dengan uji reliabilitas. Uji reliabilitas bertujuan untuk mengukur konsistensi internal terhadap konstruk indikator yang digunakan untuk mengukur derajat masingmasing indikator yang menunjukkan konstruk secara umum. Uji reliabilitas diukur dengan menghitung reliabilitas konstruk. Masalah dianalisis dengan menggunakan metode penelitian kuantitatif.

Uji reliabilitas dilakukan dengan melakukan pengujian instrumen untuk mengetahui nilai kehandalan konstruk dan varian yang diekstraksi yaitu pengujian yang dilakukan terhadap semua dimensi penelitian. Dimensi penelitian ini merupakan hasil pengembangan dan penjabaran dalam kajian pustaka terhadap empat variabel yang diteliti yaitu etika, perilaku, kepribadian dan integritas. Instrumen penelitian dikatakan memiliki tingkat kehandalan yang baik apabila nilai alpha cronbach $\geq 0,70$. Tabel 2 menunjukkan hasil uji reliabilitas dengan memanfaatkan program SPSS 22. Analisis uji reliabilitas terhadap semua indikator yang diuji harus memiliki nilai alpha cronbach $\geq 0,70$ yang artinya bahwa indikator yang diuji adalah handal atau reliabel.

Pengujian reliabilitas dilakukan terhadap semua variabel yang diteliti yang dijabarkan ke dalam dimensi penelitian. Pada variabel etika, dimensi penelitian meliputi moral, norma, dan penghormatan. Dimensi penelitian pada variabel perilaku terdiri dari psikologi, sosiologi, dan antropologi. Sedangkan dimensi penelitian pada variabel kepribadian mencakup sifat, watak, dan karakteristik. Untuk dimensi penelitian pada variabel integritas antara lain kejujuran, 
Table 2. Uji Reliabilitas Indikator

\begin{tabular}{lllll}
\hline Indikator & Mean & SD & Total Correlation & Cronbach's Alpha \\
\hline Moral & 13,389 & 1,681 & 0,390 & 0,810 \\
Norma & 14,272 & 1,719 & 0,556 & 0.798 \\
Penghormatan & 14,415 & 1,856 & 0,415 & 0.809 \\
Psikologi & 14,058 & 1,865 & 0,470 & 0.804 \\
Sosiologi & 17,143 & 2,200 & 0,269 & 0.824 \\
Antropologi & 16,643 & 1,908 & 0,476 & 0.804 \\
Sifat & 14,006 & 1,590 & 0,505 & 0.802 \\
Watak & 13,961 & 1,933 & 0,476 & 0.804 \\
Karakteristik & 11,272 & 1,693 & 0,376 & 0.811 \\
Kejujuran & 9,201 & 1,654 & 0,653 & 0.791 \\
Kebenaran & 9,772 & 1,884 & 0,545 & 0.798 \\
Konsistensi & 9,363 & 1,729 & 0,443 & 0.807 \\
Tanggung jawab & 9,669 & 1,593 & 0,422 & 0.808
\end{tabular}

kebenaran, konsistensi, dan tanggung jawab. Hasil pengujian reliabilitas dalam penelitian ini diperoleh nilai alpha cronbach terkecil terdapat pada dimensi kejujuran sebesar 0,791 dan nilai alpha cronbach terbesar adalah pada dimensi sosiologi sebesar 0,824. Syarat nilai minimal kategori handal apabila dalam pengujian alpha cronbach memiliki nilai $\geq 0,70$. Hasil pengujian reliabilitas dalam penelitian ini nilai terendah sebesar 0,791 sehingga dapat diambil kesimpulan bahwa uji reliabilitas terhadap semua dimensi yang diuji dalam penelitian ini adalah handal dan reliable.

\section{Uji SEM}

SEM (Structural Equation Modeling) merupakan salah satu jenis analisis multivariat dalam ilmu sosial dan merupakan aplikasi metode statistik untuk menganalisis beberapa variabel penelitian secara simultan atau serempak (Sholihin \& Ratmono, 2013). Uji statistik dengan memanfaatkan SEM memungkinkan bagi peneliti untuk menguji dan mengestimasi secara simultan hubungan antar variabel (Latan, 2013). Analisis data menggunakan model persamaan SEM pada umumnya menggunakan matriks kovarians sehingga model penelitian dalam bentuk yang kompleks dapat digunakan untuk mengukur varians. Pengujian hipotesis menunjukkan pengukuran analisis pengaruh dari etika dan

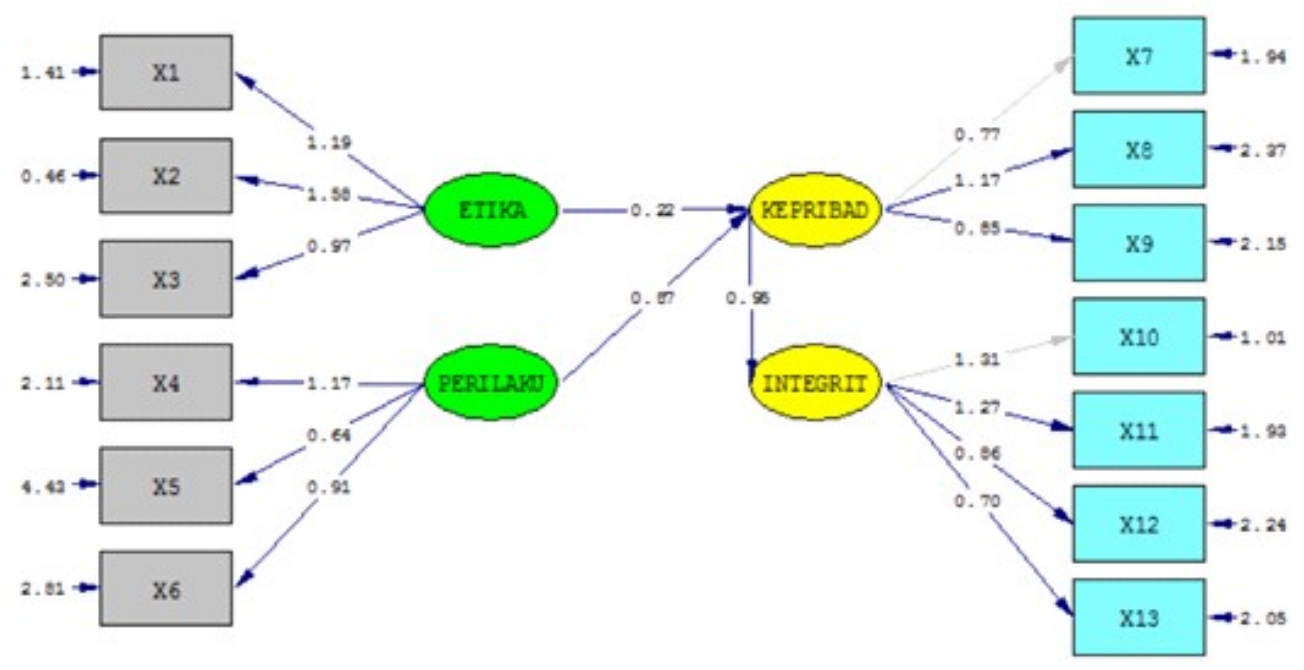

Gambar 2. Uji Hubungan Struktural Model Penelitian 
perilaku terhadap kepribadian dan implikasinya terhadap integritas guru. Gambar 2 menunjukkan model koefisien standar yang digunakan dalam uji hubungan struktur.

Hasil uji analisis menunjukkan bahwa model penelitian yang diajukan memiliki kesesuaian dengan data hasil penelitian. Penilaian indeks model struktural menunjukkan bahwa model fit sehingga layak dilakukan uji hipotesis. Dari hasil perhitungan Hipotesis $1\left(\mathrm{H}_{1}\right)$ diperoleh nilai koefisien jalur $\beta_{1=} 0,22$ dan jumlah responden $(n)=154$. Hipotesis 1 merupakan pengukuran etika terhadap kepribadian. Hasil uji hipotesis 1 menunjukkan bahwa etika guru memiliki pengaruh positif terhadap kepribadian guru. Hasil perhitungan pada hipotesis $2\left(\mathrm{H}_{2}\right)$ didapatkan nilai koefisien jalur $\beta_{2}=0,87$ dan jumlah responden $(n)=154$. Hipotesis 2 merupakan pengukuran perilaku terhadap kepribadian guru. Hasil uji hipotesis 2 menyatakan bahwa perilaku guru memiliki pengaruh positif terhadap kepribadian guru. Hasil perhitungan pada hipotesis $3\left(\mathrm{H}_{3}\right)$ diperoleh nilai koefisien jalur $\beta_{3}=0,96$ dan jumlah responden $(n)=154$. Hipotesis 3 merupakan pengukuran kepribadian terhadap integritas guru. Hasil hipotesis 3 menunjukkan bahwa kepribadian guru memiliki pengaruh positif terhadap integritas guru.

Dari ketiga pengujian hipotesis, semuanya memiliki nilai koefisien jalur lebih besar dari batas minimal loading factor yang disajikan melalui standardized solution. Selain itu, untuk mengetahui signifikansi dapat dilihat dari warna nilai koefisien jalur yang ditampilkan pada diagram path. Warna hitam pada nilai koefisien jalur berarti pengaruh atau hubungan antarvariabel tersebut signifikan dan apabila warna merah maka sebaliknya. Sedangkan pengujian hipotesis pada penelitian ini menghasilkan nilai koefisien jalur dengan warna hitam sehingga semua hipotesis dinyatakan signifikan. Hasil pengujian ketiga hipotesis memberikan bukti empiris bahwa diperlukan upaya guru dengan meningkatkan kualitas etika dan perilaku sehingga mampu memberikan pengaruh positif terhadap kepribadiannya sehingga pada akhirnya memiliki implikasi terhadap integritas guru itu sendiri. Hasil akhir pengujian model struktural yang diajukan dalam penelitian ini dapat dinyatakan diterima dan memiliki kesesuaian dengan tujuan penelitian. Kesesuaian dapat terlihat dari pengajuan rancangan model struktural dengan hasil pengujian model menggunakan SEM melalui pengukuran koefisien jalur.

Model struktural dalam pengujian SEM menunjukkan telah dipenuhinya prosedur konfirmatori faktor analisis dalam mengakses semua konstruk. Hasil model struktural yang dipaparkan pada Tabel 3 menunjukkan hasil estimasi model penelitian ini adalah fit. Indikator model fit dapat dipaparkan dengan spesifikasi pengukuran sebagai berikut: $\mathrm{Cmin} / \mathrm{df}=3,37$ $(\mathrm{Cmin}=205,69 \mathrm{df}=61) ; \mathrm{GFI}=0.82 ; \mathrm{RMR}=0.32$; $\mathrm{NFI}=0.81 ; \mathrm{CFI}=0,85 ; \mathrm{RMSEA}=0,132$. Nilai ChiSquare $\left(\chi^{2}\right)=147.56$ dimana $\chi^{2}$ mengevaluasi apakah kovarian populasi matriks sama dengan matriks kovarian model. Pengukuran Root Mean Square Error of Approximation (RMSEA) $=0,132$ yang digunakan sebagai ukuran perkiraan fit suatu model dalam populasi yang berkaitan dengan perbedaan perkiraan. Nilai Root Mean Residual $(R M R)=0,32$ yang digunakan untuk

Tabel 3. Hasil Uji SEM

\begin{tabular}{llll}
\hline Hipotesis & Hubungan struktural & $\begin{array}{l}\text { Standar Koefisien } \\
(T \text {-value })\end{array}$ & Identifikasi \\
\hline $\mathrm{H}_{1}$ & Etika $\rightarrow$ Kepribadian & $0,22(1,74)$ & Diterima \\
$\mathrm{H}_{2}$ & Perilaku $\rightarrow$ Kepribadian & $0,87(4,48)$ & Diterima \\
$\mathrm{H}_{3}$ & Kepribadian $\rightarrow$ Integritas & $0,95(5,39)$ & Diterima \\
$\mathrm{NFI}=0,83$ & NNFI $=0,86$ & $\mathrm{CFI}=0,90$ & $\mathrm{IFI}=0,90$ \\
$\mathrm{RMSEA}=0,132$ & $\chi^{2}=147.56$ & $\mathrm{df}=59$ & $p=0.000$ \\
\hline
\end{tabular}


mengukur badness of fit secara keseluruhan yang berdasarkan residual. Pengukuran Goodness of Fit Index (GFI) $=0,82$ sebagai ukuran relatif sejumlah varians dan kovarians dalam kovarians matrik empiris yang diprediksikan oleh kovarian matrik model. Nilai Normed Fit Index $(N F I)=0,81$ dan Non-Normed Fit Index $(N N F I)=$ 0,86 yang menunjukkan bahwa model target merupakan model independent yang fit, nilai yang tinggi atau mendekati 1 menunjukkan model fit dengan kategori baik. Pengukuran Comparative Fit Index $(C F I)=0,90$ merupakan pengukuran model yang terindikasi fit dan tidak dipengaruhi oleh ukuran sampel yang diteliti. Pengukuran Incremental Fit Index (IFI) $=0,90$ merupakan nilai batas fit yang dapat diterima.

Setelah menganalisis hasil pengukuran terhadap indikator pada model struktural dalam penelitian ini, hasil pengujian keseluruhan indikator secara empiris menunjukkan semua hipotesis yang diajukan dalam penelitian adalah signifikan dan dapat diterima sebagai model. Hal ini dapat dilihat dari hasil pengujian GFI, NFI, NNFI, IFI dan CFI yang memiliki nilai $>0,8$ yang artinya model struktural penelitian ini adalah signifikan. Nilai dari indeks pengukuran model struktural yang dihasilkan dalam penelitian ini menunjukkan bahwa model yang diajukan memiliki kecocokan dan menghasilkan nilai yang mampu memperkuat model sehingga dapat disimpulkan bahwa model adalah fit atau tepat. Model fit karena model SEM yang digunakan pada penelitian ini dapat digunakan sebagai estimasi. Adanya kecocokan yang dihasilkan dalam model penelitian struktural sehingga dinyatakan model fit sehingga dapat diketahui bahwa ada pengaruh antara etika guru terhadap kepribadian, ada pengaruh perilaku guru terhadap kepribadian, dan ada pengaruh kepribadian guru terhadap integritas.

\section{KESIMPULAN DAN SARAN}

\section{Simpulan}

Mengacu pada hasil dan pembahasan maka hasil penelitian dapat disimpulkan sebagai berikut. Pertama, etika guru memiliki pengaruh positif terhadap kepribadian guru. Etika pendidik perlu terus dikembangkan berkaitan dengan nilai moralitas yang dapat mencerminkan kepribadian pendidik yang diiplementasikan dalam aktivitas belajar mengajar di sekolah. Pendidik yang beretika perlu diterapkan oleh setiap guru tidak hanya pada jenjang SMA akan tetapi juga perlu diterapkan di semua jenjang pendidikan di sekolah. Kepribadian guru akan terlihat dari nilainilai pribadinya yang luhur dengan mengedepankan etika dan sikapnya dalam menghargai dan memperlakukan orang lain terutama interaksinya dengan kepala sekolah, rekan guru maupun dengan siswa. Kepribadian mampu memprediksi aspek yang berbeda pada proses emosional (Komulainen, Meskanen \& Lipsanen, 2014).

Kedua, perilaku guru memiliki pengaruh positif terhadap kepribadian guru. Melalui keseriusan dalam melakukan kejujuran dan keterbukaan maka perilaku guru dapat terbentuk dengan mengutamakan nilai moral dan etika. Perilaku guru menjadi contoh dan panutan bagi siswa dalam melaksanakan tugas profesionalnya diantaranya mendidik, mengajar, membimbing, mengarahkan, melatih, menilai serta mengevaluasi peserta didik. Guru dengan kepribadian yang baik harus memiliki kemampuan untuk beradaptasi dengan lingkungannya sehingga mudah dalam berinteraksi dengan sesama guru secara baik dan mampu bekerjasama dalam pengembangan sistem pendidikan di sekolah secara efektif dan efisien. Perilaku guru memiliki peran penting dalam meningkatkan kualitas kepribadian guru. Peningkatan profesionalisme guru dibuktikan melalui perubahan perilaku, kreativitas, dan inovasi dalam pengembangan karir (Lisnawati, 2013). Kepribadian guru mempengaruhi motivasi belajar siswa yang rendah (Andabai, 2013).

Ketiga, kepribadian guru memiliki pengaruh positif terhadap integritas guru. Untuk memiliki kepribadian yang baik maka guru harus memiliki nilai-nilai kepemimpinan, manajerial serta fleksibilitas dalam melaksanakan tugas pokok dan fungsinya. Guru profesional harus memiliki 
sifat kritis dan mampu berfikir analitis sebagai bentuk kepribadian dari keilmuannya. Sifat pendidik dapat terlihat dari integritasnya terhadap berbagai nilai dalam pelaksanaan sistem pembelajaran di sekolah. Peran penting guru untuk mencapai integritas tinggi dalam meningkatkan kualitas sistem pembelajaran sangat diperlukan melalui upaya secara bersama-sama dengan mengembangkan etika, perilaku dan kepribadian yang lebih baik. Integritas guru memiliki dampak terhadap pengembangan moral siswa (Mureithi, Nyaga, Barchok, \& Oundo, 2013). Integritas dipahami dalam konteks perilaku dan perilaku integritas pada umumnya dipahami dalam kaitannya dengan etika dan moral (Sri-Redjeki \& Heridiansyah, 2013). Integritas dikaitkan dengan sikap jujur, dapat dipercaya, bertanggung jawab, setia, dan dapat menahan diri (Gea, 2014).

\section{Saran}

Mengacu pada simpulan dirumuskan saran-saran sebagai berikut. Pertama, guru dalam bertindak diharapkan selalu memperhatikan dan memperhitungkan nilai-nilai etika dalam melaksanakan tugasnya secara profesional karena dapat mempengaruhi kualitas kepribadiannya. Pengembangkan nilai etika yang baik diantaranya dengan cara menjaga hubungan baik dan menjaga nilai kesetiakawanan dengan semua stakeholder di sekolah sehingga guru memiliki kepribadian unggul yang tercermin dalam tindakannya yang mengedepankan norma yang berlaku di masyarakat.
Kedua, perilaku guru harus dijaga dan dipelihara dengan baik karena dapat memengaruhi kepribadiannya. Guru dalam melaksanakan kegiatan pembelajaran di sekolah harus mengedepankan perilakunya secara baik, memiliki kontribusi yang signifikan terhadap kualitas kepribadiannya, dan pada akhirnya dapat mencerminkan integritas guru yang sebenarnya. Guru juga dituntut untuk berperilaku jujur dalam melaksanakan tugas dan kewajibannya. Keterbukaan dalam proses belajar mengajar dianggap penting bagi pemangku kepentingan khususnya peserta didik agar proses pembelajaran dapat dilakukan lebih efektif dan efisien serta mampu mengembangkan model pembelajaran terkini yang memudahkan peserta didik memahami materi yang diajarkan.

Ketiga, guru harus memiliki kepribadian unggul karena dapat memengaruhi integritasnya. Dengan mengembangkan nilai-nilai kepemimpinan dan manajerial bagi guru sehingga guru dengan kepribadian unggul akan terbentuk. Sifat kritis dan kemampuan dalam melakukan analisis merupakan faktor yang dapat menciptakan kepribadian yang unggul. Pentingnya nilai integritas yang tinggi harus dimiliki guru dari berbagai jenjang pendidikan khususnya dalam melaksanakan tugas pokok dan fungsinya sebagai pendidik maupun sebagai pengajar di sekolah. Guru diharapkan memiliki nilai etika yang lebih baik, berperilaku yang terpuji, dan berkepribadian yang luhur serta memiliki integritas yang tinggi khususnya dalam melaksanakan proses pembelajaran di sekolah.

\section{PUSTAKA ACUAN}

Andabai, P. W. 2013. Teacher's Personality and Classroom Management of Tertiary Institutions in Nigeria: The Issues and Perspectives. Academic Journal of Interdisciplinary Studies, 2(5), 73-78.

Audi, R. \& Murphy, P. E. 2006. The Many Faces of Integrity. Journal of Business Ethics Quarterly, 16(1), 30-21.

Bielefeldt, A. R., Swan, C., Canney, N., \& Knight, D. W. 2016. Contributions of Learning Through Service to The Ethics Education of Engineering Students. International Journal for Service Learning in Engineering, 11(2), 1-17. 
Chari, S. N., Gupta, M. M., \& Gade, S. A. 2016. Developing and Validating Curriculum For Administrative Skills Workshop For Departmental Heads of Medical College. International Journal of Current Research and Review, 8(17), 4-9.

Dianti, P. 2014. Integrasi Pendidikan Karakter Dalam Pembelajaran Pendidikan Kewarganegaraan Untuk Mengembangkan Karakter Siswa. Jurnal Pendidikan Ilmu Sosial, 23(1), 58-68.

Djamarah, S. B. 2010. Guru Dan Anak Didik Dalam Interaksi Edukatif. Jakarta: Rineka Cipta.

Dutelle, A. W. 2011. Ethics For The Public Service Professional. Boca Raton: CRC Press.

Ferrell, O. C. 2013. Business Ethics: Ethical Decision Making and Cases, $9^{\text {th }}$ Edition. South Western: Cengage Learning.

Gade, S. 2015. Kode Etik Pendidik Menurut Ibnu Jama'ah. Jurnal Pencerahan, 9(1), 23-36.

Gea, A. A. 2014. Integritas dan Kepemimpinan Etis. Jurnal Humaniora, 5(2), 950-959.

Griffin, R. W., \& Moorhead, G. 2014. Organizational Behavior: Managing People and Organizations, Eleventh Edition. South-Western: Cengage Learning.

Groisman, I. J., \& Godard, B. 2016. Impact of Next Generation Sequencing on The Organization and Funding of Returning Research Results: Survey of Canadian Research Ethics Boards Members. Journal of Plos One, 11(5), 1-13.

Hadjam, M. N. R. 2013. Peranan Kepribadian dan Stres Kehidupan Terhadap Gangguan Somatisasi. Jurnal Psikologi, 1, 36-56.

Hamalik, O. 2000. Psikologi Belajar dan Mengajar. Bandung: Sinar Baru Algessindo.

Kabus, N. 2017. Prospective Social Workers' Training to Sustainable Development of Social Groups on the Basis of System-Synergetic Approach. Journal of World Scientific News, 61(2) 110-121.

Karwati, E. 2011. Etika Pengelolaan Pendidikan Untuk Menjamin Kualitas dan Profesionalisme. Bandung: Alfabeta.

Komulainen, E., Meskanen, K., \& Lipsanen, J. 2014. The Effect of Personality on Daily Life Emotional Processes. Journal of Plos One, 9(10), 1-9.

Latan, H. 2013. Sructural Equation Modeling, Konsep dan Aplikasi Menggunakan Program Lisrel 8.80. Bandung: Alfabeta.

Linstrom, S. 2016. Artist and Multiple Job Holding-Breadwinning Work as Mediating Between Bohemian and Entrepreneurial Identities and Behavior. Nordic Journal of Working Life Studies, 6(3), 43-58.

Lisnawati, T. A. N. 2013. Peranan MGMP IPS SMP Komda Pati Dalam Peningkatan Profesionalisme Guru Pendidikan IPS. Journal of Educational Social Studies, 2(1), 16-21.

Lubis, D. 2011. Etika Pendidikan dan Pengembangan Sumber Daya Manusia. Bandung: Alfabeta.

MacKinnon, B. 2013. Ethics: Theory \& Contemporary Issues - Concise, $2^{\text {nd }}$ Edition. Boston: Cengage Learning.

Mermer, G., Daghan, S., \& Bilge, A. 2016. Prevalence of Tobbaco Use Among School Teacher and Effect of Training on Tobbaco Use in Western Turkey. Central European Journal of Public Health, 24(2), 137-143.

Mesbahi, M. 2016. Mediator Role of Social Capital and Organizational Commitment in The Relation of Service-Oriented Motivation and Organizational Citizenship Behavior. Journal of World Scientific News, 64, 54-68. 
Mroz, J., \& Kaleta, K. 2016. Relationships Between Personality, Emotional Labor, Work Engagement, and Job Satisfaction in Servive Professions. International Journal of Occupational Medicine and Environmental Health, 29(5), 767-782.

Muchlas, M. 2008. Perilaku Organisasi. Yogyakarta: Gadjah Mada University Press.

Munir, M. 2009. Etika Guru. Jurnal Studi Islam Madinah, 2(2), 66-75.

Mureithi, M. M., Nyaga, V. K., Barchok, H. K., \& Oundo, M. B. 2013. Influence of School Factors on Development of Academic and Moral Competence of Secondary School Students' in Embu West District, Kenya. International Journal of Humanities and Social Science, 3(19), 186-190.

Muryadi \& Matulessy, A. 2012. Religiusitas, Kecerdasan Emosi dan Perilaku Prososial Guru. Jurnal Psikologi, 7(2), 544-561.

Navisah, E. 2009. Persepsi Siswa Terhadap Kepribadian Guru PAI Hubungannya Dengan Minat Belajar Siswa Pada Mata Pelajaran PAI. Jurnal Pendidikan Universitas Garut, 03(01), 1013.

Ninoersy, T. 2015. Integritas Pendidik Profesional dalam Tinjauan Al-Qur'an. Jurnal Edukasi, 1(2), 113-135.

Nofijantie, L. 2014. Peran Lembaga Pendidikan Formal Sebagai Modal Utama Membangun Karakter Siswa, Jurnal Al-Tajdid, 3(1), 45-71.

Nursyamsi. 2014. Pengembangan Kepribadian Guru. Jurnal Al-Ta'lim, 21(1), 32-41.

Peraturan Menteri Pendidikan Nasional Republik Indonesia Nomor 16 Tahun 2007 tentang standar kualifikasi akademik dan kompetensi guru.

Rahrovan, A. 2016. Teacher's Feature and Its Role in Student's Social Education. Journal of Current Research in Scince, 4(2), 74-76.

Rice, L. L., \& Foster, D. D. 2016. An International and Domestic Examination of Faculty Epistemological and Pedagogical Teaching Beliefs. Nacta Journal, 60(3), 334-342.

Robbins, S. P., \& Judge, T. A. 2013. Organizational Behavior, $15^{\text {th }}$ Edition. New Jersey: Pearson Education Inc.

Rosmiati., Juraid., \& Hasan. 2016. Hubungan Sifat Kepribadian Guru IPS Terhadap Motivasi Belajar Siswa Dalam Proses Pembelajaran Pada MTs Negeri di Kota Palu. e-Jurnal Katalogis, 4(7), 84-94.

Rosyidi, H. 2012. Kepribadian Dalam Perspektif Al-Furqan. Jurnal Bimbingan dan Konseling Islam, 02(01), 19-26.

Sadr, F. A., \& Jenaabadi, H. 2015. Assessing Nurses' Organizational Health Based on Their Personality Traits and Mental Health. European Online Journal of Natural and Social Sciences, 4(1), 669-676.

Sahriansyah, Yulizar, M. A., \& Khaliq, A. 2015. Pemikiran Pendidikan Tokoh-Tokoh Muhammadiyah di Kalimantan Selatan. Jurnal Tashwir, 3(6), 227-243.

Sarjana, S. 2014. Pengaruh Kepemimpinan dan Kerjasama Tim Terhadap Etika Kerja Guru SMK. Jurnal Pendidikan dan Kebudayaan, 20(2), 234-250.

Sholihin, M., \& Ratmono, D. 2013. Analisis SEM-PLS Dengan WarpPLS 3.0. Yogyakarta: Penerbit Andi. 
Silahuddin. 2016. Media Teknologi dan Implikasinya Dalam Pengembangan Pendidikan. Jurnal Circuit, 2(1), 199-207.

Sri-Redjeki, D. P., \& Heridiansyah, J. 2013. Memahami Sebuah Konsep Integritas. Jurnal STIE Semarang, 5(3), 1-14.

Sunengsih, N. D. 2015. Hubungan Profesionalisme, Iklim Sekolah dan Integritas Dengan Kinerja Guru SMP Negeri di Kota Administrasi Jakarta Timur. Jurnal Manajemen, XIX(02), 190-204.

Surya, M. 2013. Psikologi Guru, Konsep dan Aplikasi Guru Untuk Guru. Bandung: Alfabeta.

Susanna. 2014. Kepribadian Guru PAI dan Tantangan Globalisasi. Jurnal Mudarrisuna, 4(2), 376396.

Tanhidy, J. 2015. Karakteristik Sekolah Yang Berhasil dan Implikasinya Bagi Pendidikan Teologi di Indonesia. Jurnal Simpson, 2(1), 99-114.

Usman, N. 2010. Model Stratejik Peningkatan Kinerja Guru. Jurnal Ilmu Pendidikan, 17(1), 22-35.

Verrinder, J. M., Ostini, M., \& Phillips, C. J. C. 2016. Differences in Moral Judgement on Animal and Human Ethics Issues Between University Student in Animal-Related, Human Madical and Arts Program. Journal of Plos One, 11(3), 1-15.

You, X., Wang, L., \& Tan, H. 2016. Near Work Related Behaviors Associated With Myopic Shifts Among Primary School Students in The Jiading District of Shanghai: A School-Based OneYear Cohort Study. Journal of Plos One, 11(5), 1-17. 